\title{
Decolonizing Pacific Studies: Indigenous \\ Perspectives, Knowledge, and Wisdom in \\ Higher Education
}

Konai Helu Thaman

Fakatapu mo e tangata'i fonua 'o Hawai'i kae'uma'a 'a kimoutolu katoa
ka e 'ata kia teau ke hoko atu'a e katoanga lea 'o e 'abo ni. I wish to
acknowledge the presence of the spirit of the indigenous people of Hawai'i,
on whose land we happen to be meeting today, and seek their mana on this
important occasion. I would also like to congratulate the Center for Pacific
Islands Studies for fifty years of service and thank the organizers for invit-
ing me to give a keynote on a topic that has been a preoccupation of mine
for most of my working life.

As you can see, my western education has not caused me to shift from a belief and reliance in the supernatural to what Nietzsche called "the will to power," associated with human triumph over the forces of nature. I am a Tongan woman of the commoner class, and although schooled in western ways, I continue to see myself as part of an organic unity, not as a chance result of natural selection at work in a world devoid of supernatural guidance.

I apologize in advance if I say anything that offends any of you, but since I am only a teacher who dabbles in poetry, I'll try and weave a kakala (garland) for you today that is worthy of this special occasion.

Perhaps I should first "decolonize" my keynote by not offering to define terms, as my university education would have me do. Nevertheless, I suggest that the conference theme, "Decolonizing Pacific Studies," is part of the more general theme of decolonization, which, for me, implies an attempt to reflect critically on the nature, scope, and processes of colonialism in the Pacific Islands (or Oceania), particularly its impact on colonized people and their environments. While much has been written about

The Contemporary Pacific, Volume I5, Number I, Spring 2003, I-I7

(C) 2003 by University of Hawai'i Press 
the impact of colonialism on Pacific economies, environments, politics, and social structures, little attention has been focused on its impact on people's minds, particularly on their ways of knowing, their views of who and what they are, and what they consider worthwhile to teach and to learn. Although I agreed with Hereniko's comment in the preconference discussion when he said that we could not really decolonize the mind because of our need to read and write (2000), I think we can perhaps try to read and write more critically.

In my language, to study is ako, a term that is also used for education, which I define as an introduction to worthwhile learning. In this sense, Pacific studies should include knowledge, skills, and values relating to the Pacific region that are considered worthwhile to teach and to learn. The extent of what counts as "Pacific" is, of course, a matter for debate, but my Pacific is Oceania, in the sense that Hau'ofa (1993) uses the term. My address will therefore focus on the importance of recognizing and including the perspectives, knowledge, and worldviews of the indigenous peoples of Oceania in the curricula of formal education, particularly higher education.

The way we interrogate the various themes of this conference depends on a number of factors, including the particular cultural contexts in which we have been socialized, the type of formal education we've had, our beliefs and values, as well as the universities with which we identify. As a Tongan woman schooled in the traditions of New Zealand and American universities, now working at the University of the South Pacific, I have created for myself a philosophy of teaching and learning that is sourced from different cultures and traditions but rooted in Tongan culture.

For most of us who identify with Oceanic cultures, the theme of decolonizing Pacific studies is about our struggles, from kindergarten to university, to learn the dominant study paradigms and worldviews of western peoples who lived in other places at other times. This conference challenges us to look at our western educational legacies, their philosophies, ideologies, and pedagogies, which for nearly 200 years have not fully recognized the way Oceanic peoples communicate, think, and learnideologies that sought to destroy the values and belief systems underpinning indigenous education systems in which the majority of Oceanic peoples were and continue to be socialized. As a teacher who is still a learner, I think decolonizing Pacific studies is about reclaiming indigenous Oceanic perspectives, knowledge, and wisdom that have been devalued or suppressed because they were or are not considered important or worthwhile. 
For me, decolonizing Pacific studies is important because (I) it is about acknowledging and recognizing the dominance of western philosophy, content, and pedagogy in the lives and the education of Pacific peoples; (2) it is about valuing alternative ways of thinking about our world, particularly those rooted in the indigenous cultures of Oceanic peoples; and (3) it is about developing a new philosophy of education that is culturally inclusive and gender sensitive.

\section{Western Discourse and Power}

As I said at the outset, I am grateful to the Center for Pacific Islands Studies for inviting me to participate in this conference and to share in the center's celebration of fifty years of contribution to university study and scholarship. However, I need not remind you that this conference and the discussions in which we are about to engage are not beyond criticism, for several reasons. First, most of us have been schooled in western traditions of research and scholarship with their own categories, languages, images, and ideas. We will use these to describe and represent the various conference themes, fitting them into western conceptual frameworks, and further absorbing them into western academic traditions and representations, using a language that is sometimes foreign to us.

Second, much of what we label Pacific studies is the fruit of western scholarship and research. Outside researchers had their own purposes when they set out to explore and study our Pacific region. Sometimes their interests conflicted with those of the people they researched. However, most generally and genuinely believed that what they were doing would benefit those they studied and therefore could not see the contradictions.

Finally, our discussions are not exempt from critique because a discourse between western academic researchers and Oceanic peoples does not represent an encounter between equals, and researchers' cultures often influence what they see or do not see. What we might perceive to constitute Pacific studies (knowledge) therefore constitutes a type of power exercised over those who are "studied" or "known," and those who produce the discourse (that is, we) have the power to enforce its validity and its scientific status and make it "true."

your way

objective

analytic

always doubting 


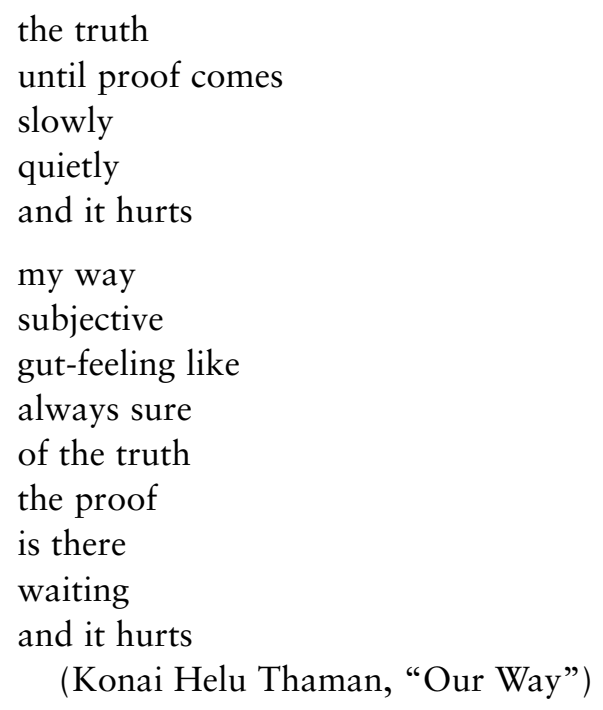

Pacific studies, therefore, like all types of university studies, continues to be dominated by western, scientific, and liberal thinking. Most of you are no doubt familiar with the critical writings of intellectuals such as Albert Memmi (I965), Franz Fanon (I967; 1986) and Edward Said (I978), who protested intellectual colonization by the West. Closer to home, Roberta Sykes has exposed the annihilation of indigenous Australians and the ongoing eradication of indigenous languages, wisdom, and knowledge in contemporary Australian society (1989). Linda Tuhiwai Smith, looking through the eyes of the colonized, has interrogated western research paradigms, urging culturally appropriate practices and the conscious development of indigenous peoples as researchers (I999). All these writers, reflecting critically on the processes whereby ways of knowing used in western, economically developed countries continue to be cultivated in our universities and region, have called for a paradigm shift.

\section{Europeans' Pacific and Europeans' Studies}

If we were to apply Said's suggestions about the Orient to the Pacific, we might conclude that what we delineate as "the Pacific" had been produced politically, socially, ideologically, and militarily by westerners. Pacific studies' earliest roots grew out of common assumptions held by outsiders, who used them to explain people's behavior, supplying Pacific peoples with a mentality and a history the colonizers could deal with. In their assump- 
tions, early visitors and researchers drew on sources of information ranging from biblical to mythical, for example, when Bougainville called Tahiti the new Cythera, after the island where Venus first appeared from the sea. Just as they came to see Jerusalem as the center of the earth, Asia as the home of the three kings, and Africa as the home of King Solomon, they perceived Polynesia as an enchanted garden or paradise. Classical western sources framed the perspectives through which western writers and researchers saw, described, and represented Pacific peoples, places, and things. Modern scholars and writers, including some of us here today, continue to represent the Pacific using frameworks associated with the different university disciplines in which we have been schooled. Through both facts and fantasy therefore, Pacific studies has been constituted, defined, and perpetuated as an integral part of western knowledge and modern social science.

Today, as we gather to reflect on the past and help shape the future, we, particularly those of us whose identities are closely linked to Oceania, need to interrogate the images and the representations that we have inherited or are creating. This is important because we often see the ideas we have inherited from the academy as natural and inevitable and we accept them as "truths," incorporating them into the way in which we organize and manage ourselves, our work, and our lives. As academics and researchers, we produce "knowledge" through the "truths" that we present and deliver. In other words, Pacific studies is structured the way it is because the theories and ideologies associated with it have themselves become "truths" that serve to proclaim desired outcomes as normal and natural, and those who see things differently are rebuffed as pathological. We must therefore be careful not to advocate something simply because our own education has largely been structured by it or our jobs depend entirely on it. In saying this I do acknowledge the difficulty of addressing this theme since I, like many of you here today, carry the same, multiple, unconscious premises and unexamined assumptions of various colonizers in my head:

today your words are empty sucking dry the brown dust left by earth and sky patches politely parched with no water flowing from the mountain top 
scars burn on my soft skin

you've cut a piece of me away

leaving my bandaged heart

to endure the pain

of your tying me

to yourself

(Konai Helu Thaman, "Your Words”)

\section{Culture and Decolonization}

If Decolonizing Pacific Studies is about decolonizing the mind, then it is about culture. The idea that culture includes the human mind is of course not new; it became evident in Europe in the sixteenth century (before that, culture referred to the domestication of animals and crops, as in "agriculture" and "horticulture"). People then began using the term "cultured" to refer to those who were wealthy and who were associated with western arts, music, literature, theatre, and sculpture. Later western scholarship, history, and philosophy were added (Williams I983), but it was always assumed that some ways of life were more valuable than others.

This use of "culture" reflected a view of unilinear social development with Europe at the top, which persisted until the early twentieth century, when people began to refer to "cultures" in the plural. Anthropologists and sociologists used culture to refer to distinctive ways of life, shared values, meanings etc. of different groups at different times, and Pacific "cultures" as you know, became objects of anthropological study. More recently, however, some scholars have focused on what has been referred to as the "symbolic dimension of culture," emphasizing what culture does rather than what it is. Still others see culture as social practice rather than as a thing (such as the arts) or a state of being (civilization), an approach that is grounded in the study of language and meaning. This shift to symbolic representation implies that decolonizing Pacific studies will have to involve the study of representations.

Pacific studies as a study of representations is important, in my view, because science, as a system of representations, makes claim to the universal significance of science and the scientific method. This method has been questioned by many scholars, including Max Weber, who argued that while science makes the world orderly it does not necessarily make it meaningful. Beare and Slaughter (1993) have encouraged the critical 
examination of the scientific method and ask schools and universities in Australia to go beyond scientific rationalism in their curricula. More recently, Mere Roberts (2000) has suggested that decolonizing science is problematic and suggests that there is a need for the academy to consciously make room for indigenous knowledge systems, warning that for New Zealand, the Treaty of Waitangi makes this an imperative for all university teaching.

Decolonizing Pacific studies is also important because it is about recognizing that today, globalization, however defined, concerns the global spread of mainly Anglo-American knowledge, values, and practices, rather than indigenous knowledge and wisdom. Globalization, like colonization, is once again disempowering many Oceanic peoples, especially those who are most removed from western knowledge and values, causing the United Nation's Educational, Scientific, and Cultural Organization (UNESCO) to warn that the mass export of the cultural practices and values of the industrialized world, including their languages, communication, and entertainment networks and unsustainable consumerism, may well contribute to a sense of dispossession and loss of identity among those who are exposed to it (Teasdale $\mathrm{I997,}$ I). Critical reflection on the philosophy of science and liberal education, as well as what passes for "objective" truths, will reveal that our academic education is not culture-free and gender-neutral, nor does it occupy an ideologically neutral high ground because academic, scientific, and liberal beliefs and values, like all beliefs and values, are embedded in a particular cultural curriculum and agenda (Vine I992, I69-2 I0).

The global spread of western cultures, to which universities have made a huge contribution, may be compared to the spread of monocultures in agriculture where imported, hybridized, fertilizer-dependent seeds, produced at a profit for multinational corporations, crowd out indigenous local varieties. My work as well as those of my students in the area of indigenous education in Oceania has shown the conflicting emphases between indigenous educational systems and the inevitable march toward the rationalization of globalized culture and globalized education (Thaman I998).

As educators, it is our responsibility to make learners aware of these tensions and encourage the call for their critical analysis. In my work at the University of the South Pacific, I recognize the dominant paradigms that have limited educational discourses so far, and I advocate the incor- 
poration of indigenous and local knowledge and wisdom into the content of all courses offered at our university so as to encourage the valuing of ways of knowing and knowledge associated with Oceanic peoples and the acceptance of their multiple wisdoms. It is my belief that this approach ought to form the core of Pacific studies teaching and research in the future.

\section{INDIGENOUS WAYS OF THINKING}

Although the United Nations definition of "indigenous" clearly leaves out most of the indigenous peoples of Oceania (because most are not minorities in their own lands), I do include them in my consideration of "indigenous" for two reasons. First, with the exception of the "Atenisi Institute in Tonga, formal educational institutions, particularly those of higher education, have not regarded Oceanic cultural knowledge, skills, and values as worthy of inclusion in academic study. Second, the expansion of the global market economy is actually destroying rather than promoting Oceanic economic and social development. Despite arguments from international consultants and advisors, western-derived economic and educational developments have destroyed important aspects of Oceanic cultures, including languages, as well as social, political, and economic structures. Global (read western, industrial, and scientific) culture, like modern education, is a mixed blessing, as the human, cultural, and ecological consequences of modern development become more obvious, and an increasing number of people are now asking the question, Is there only one path to modernity?

Recent moves by some scholars to reconnect with indigenous ways of thinking about society and education have generally been focused on students' educational underachievement and in reaction against the kind of scientific, reductionist thinking that has come to be associated with global market economic structures. It is interesting to note that what is happening to indigenous peoples in Oceania is not dissimilar to what happened in medieval Europe when agricultural lands passed into private hands at a time of great technological innovations in transportation (such as improvements in river navigation, the dredging of canals, and the development of rail and road transport). As a consequence, the communal self-sufficiency that had characterized medieval life on the manor estate and the village common gave way to a diversified market economy that depended on expanding markets, improved transportation, and overseas trade, all of 
which required new forms of regulation, coordination, and control. People then, like many indigenous people now, lost far more than their ancestral land as privatization shattered the entire structure of life, and with it the spiritual as well as the economic security that for thousands of years had provided indigenous peoples with a sense of place and purpose. Exposed and directionless, many were at the mercy of wealthy landlords, capitalist merchants, and factory owners. More recently, the dispossessed have suffered at the hands of bureaucrats and autocrats of the nationstate.

Other aspects of global economic colonization impact indigenous peoples in general and Oceanic peoples in particular. In less than thirty years, the great atmospheric commons has been divided up, nationalized, partly privatized, and reduced to a commodity that is negotiable in the open global marketplace. The electromagnetic commons has also been enclosed. With the invention and use of new information technologies, enclosed bands are regulated by the International Telecommunication Union and questions are now being asked about the desirability of high-tech nations and global corporations pushing ahead to create a new global information society (Rifkin I992, 6I). As the information debate progresses, the issue of spectrum allocation has become intensely politicized, and arguments concerning a particular use of the shortwave or a particular band within the gigahertz range have taken on the same kind of ideological coloration as arguments over oil resources, frontiers, or coffee prices (Smith I999, I2I). And as some of you may know, gene pools have also been commoditized (and the United States may be the first nation to formally eliminate any distinction that might exist between live and inanimate objects).

Pacific studies has not always valued indigenous perspectives. Today is a rare occasion when a keynote is devoted to indigenous issues; usually they are included in a discussion about multicultural education, or traditional knowledge of hard-to-reach clients of educational and other organizations. Even at the 1990 World Conference on Education for All, in Jomtien, Thailand, indigenous people were seen as clients who needed to become literate in order to boost the statistics of educational achievement in countries with high illiteracy rates so as to contribute to increases in their gross national products.

The Commission on Indigenous Education, held in Sydney in 1996 as part of the Ninth World Congress of Comparative Education, recognized the voices of indigenous peoples in all spheres of intellectual life, and noted that many of them do not share the dominant, globalized educa- 
tional and economic agendas. Before that, in a 1992 conference sponsored by UNESCO in Rarotonga, educators from many Pacific Island nations, as well as Māori and Aboriginal educators from Aotearoa and Australia, reaffirmed the role of Pacific cultures in their educational development. They also agreed that indigenous peoples' voices must be heard and their perspectives count in matters that concern them and their environments. But in reality having indigenous perspectives count in anything important is always a struggle, as two indigenous educators have reminded us: Wendy Brady of Australia stated: "My ancestors had in place systems of education, cultural practice and maintenance, spirituality and social cohesion which sustained them for 40,000 years. After 208 years of colonisation we are left with a legacy of grief, dispossession and struggle for survival. I believe that it is time we empowered ourselves to take back our education so that we can move with pride into our next 40,000 years" (I997, 42I). And Linda Tuhiwai Smith of Aotearoa wrote: "It galls us that Western researchers and intellectuals can assume to know all that it is possible to know of us, on the basis of their brief encounters with some of us. It appalls us that the West can desire, extract and claim ownership of our ways of knowing, our imagery, the things we create and produce and then simultaneously reject the people who created and developed those ideas and seek to deny them further opportunities to be creators of their own culture and own nations" (I999, I).

Smith went on to suggest (and I agree) that indigenous peoples' perspectives have been silenced, misrepresented, ridiculed, and even condemned in academic as well as popular discourses. Some of us here today know how it feels to have our work treated in this way. I recall how an article of mine was considered unfit for publication in a book because there was too much of me in it; it was too different, too personal, and too Tongan. In another scenario, a course in Pacific literature was dropped from the requirements for a bachelor's degree in literature at our university because the head of department, an American, considered Pacific literature "unsubstantial" and suggested instead that it could be offered as part of a course in commonwealth literature. I'm sure some of you can provide your own examples from your experiences as well as from the experiences of others that you know about.

Decolonizing formal education involves accepting indigenous and alternative ways of seeing the world. For academics, it means accepting Pacific perspectives, ways of knowing, and wisdom, and encouraging efforts by 
staff and students alike to reclaim indigenous knowledge as well as philosophies of teaching and learning that encompass the multiple experiences of Oceanic peoples. In higher education, such a shift is important not only for pedagogic reasons, but is an important part of Pacific studies itself, and depending on the context, we can either make such an approach our mission, as I suggest Pacific studies at the University of the South Pacific ought to do, or as an important theme that is woven into teaching and research, as other Pacific studies units elsewhere might do.

Including indigenous perspectives in higher education is an imperative now for several reasons: Vibrant indigenous cultures in the world today have their own views of the world that must be recognized and acknowledged. Institutions of high education must recognize ownership and control of indigenous knowledge by indigenous peoples rather than by the academy. Pacific studies centers and programs need indigenous cultural knowledge in order to validate and legitimize their work, particularly in the eyes of indigenous peoples. Indigenous knowledge can contribute to the general knowledge base of higher education and enrich the curriculum by considerations of different perspectives of knowledge and wisdom. Incorporating aspects of indigenous education into course curricula helps make university study more meaningful for many students. Valuing indigenous ways of knowing usually results in mutually beneficial collaboration between indigenous and nonindigenous peoples, and improves their treatment of each other as equals.

When I was an undergraduate student at Auckland University in the I960s I learned that in order to be modern and successful at university I had to hang my cultural orientation and identification on the trees at Albert Park and forget who I was for a while. But this is the twenty-first century and things have changed. Postmodernists tell us that there is no real justification for claiming that any type of knowledge or perspective is a better representation of reality than any other, making different perspectives just as valid and worthwhile as one's own.

I am attracted to postmodernism because I never liked the westerndominated, monocultural, assimilationist view of the world I had learned at university, and I wanted to be able to name and represent my thoughts and feelings, to speak for myself, and to create my own version of history. As a young, inexperienced lecturer at the University of the South Pacific, I was fortunate to work with people who valued the perspectives of Pacific peoples, and who, through example and advocacy, helped me find my 
voice; some of you are here today and you have my gratitude. In the academy today, we continue to need such people who value and encourage the multiple voices of the people of Oceania, and facilitate their creation for themselves of spaces in which they feel comfortable.

However, postmodernism does not provide all the answers. In my view, its ahistorical representation of social life as a continuing conflict between the colonizer and the colonized denies Oceanic cultures a past without Europeans and their colonizing activities. Indigenous peoples have cultural histories that are long, authentic, and material to the well being of all their people, whether they live in the region or not. To view the Pacific only from the perspective of European colonization does not do justice to the region's indigenous peoples.

I suggest that indigenous worldviews are good for the future of university studies. An inclusive and holistic way of thinking champions stewarding nature, participating in community, and valuing interpersonal relationships. It compliments beliefs in rational objective thinking, suspicion of emotions and feelings, material productivity, and personal autonomy. It is akin to "transformational politics" and "therapeutic consciousness," currently two "cool" alternatives to mechanistic consciousness and thinking. Finally, indigenous wisdom is nothing new; before the modern age, every civilization viewed the earth as alive, as an organism with a set of living relationships working together. Today, while modern global technology allows us to be detached from the earth and from people, indigenous wisdom is about the connectedness and interrelatedness of all things and all people.

A recent publication entitled Local Knowledge and Wisdom in Higher Education (Teasdale and Rhea 2000) contains numerous case studies illustrating how various people have incorporated indigenous knowledge and perspectives in the curriculum of higher education, particularly in programs involving the education of teachers. Cases are drawn from the Pacific as well as from Asia, North and South America as well as Africa and the Caribbean. Authors highlight the highly contextualized and holistic nature of indigenous educational philosophies, in contrast with the fragmented, mechanical, empirically based, and individualized nature of western thinking on which formal education, particularly higher education, is based.

My chapter in Local Knowledge is an account of an education course that I teach at the University of the South Pacific, in which, through an examination of their vernacular languages, students explore how vernac- 
ular philosophies of education are embedded in local cultures and languages (Thaman 2000). Students learn to compare the educational values of their own culture with those of the western canon. Although I am aware of objections from high-status universities of the West to what they call "area" studies or "ethnic" studies because they elevate the lesser writers to the status of so-called "great" writers, my course does exactly that. My course has been referred to as an example of cultural resistance (Teasdale and Rhea 2000, xxiii), but I see it as students reclaiming their education, an important part of the ongoing process of decolonizing higher education in the Pacific.

The nature of the new information age today means that some forms of local knowledge (those belonging to the center) are benefiting from universal electronic distribution while others (those of the periphery) are deemed marginal. Political power and power relations are obviously involved in the designation of what is so local as to be thought "peripheral" and what is so central as to be thought "great" (see Galtung's work [1973] on center-periphery theory). The workings of World Wide Web mean that the dissemination of knowledge via books and the Internet can also be controlled by those in the center. Pacific studies centers are in an ideal position to encourage and support local efforts to reclaim cultural democracy in the academy and disseminate these in appropriate ways. Here, collaborations with indigenous communities are necessary in order to ensure that control and ownership issues are worked out satisfactorily.

A paradigm shift and a search for multiple perspectives and alternative ways of looking at the world will enrich and enhance our understanding of Pacific studies, not diminish or degrade it. For example, take Pacific literature in general, and my poetry in particular. My poems are expressions of thoughts and feelings about different phenomena, and although I use the English language, I draw from the richness of Polynesian epistemologies as well as contemporary Pacific cultures. My readers, like the community in which our artists work, are part-owners of my poems; hence, understanding the cultural contexts of my writing opens up more possibilities for multiple interpretations. To have a deeper appreciation of my writing one has to have some understanding of indigenous cultures in general and Tongan culture in particular, and the values that underpin these. Unfortunately, few literary critics, including those at our university, have explored this aspect of my writing.

Finally, in decolonizing Pacific studies, I suggest that we also need to go beyond the politics of society into the politics of individual consciousness, 
for worldviews are not only cultural and social abstractions but also the embodiment of our sense of self in the world. It is the way we think and our capacity for wisdom that ultimately produce the world we live in now and shape the world of the future (Teasdale and Rhea 2000, I). Transforming Pacific studies will require transforming the personal politics of those of us who are involved in it, because our acquired worldview represents our flight from our cultural roots and from nature and a drive for autonomy, much of which might have isolated many of us from our environment and from one another. We must examine our own ways of thinking and knowing and explore how they might be changed in order to create a Pacific studies that is Pacific in orientation and inclusive in its processes, contexts, and outcomes.

\section{Conclusion}

To conclude, I leave you with a couple of questions: What relationship do your ideas have to locally recognized concepts of knowledge and wisdom? And how are globally available, academically generated ideas able to articulate with the needs of Oceanic peoples and communities such that they can foster a better way of living at this time, let alone the future? Many people outside the academy have pointed out that humanity needs wisdom to face the twenty-first century, but little heed of this has been taken in academic literature. The challenge for all of us at this conference is not whether incorporating indigenous perspectives and wisdom in higher education is right or wrong, but whether we are ready to give other ways and other voices a chance.

you say that you think

therefore you are

but thinking belongs

in the depths of the earth

we simply borrow

what we need to know

these islands the sky

the surrounding sea

the trees the birds

and all that are free

the misty rain

the surging river

pools by the blowholes 
a hidden flower

have their own thinking

they are different frames

of mind that cannot fit

in a small selfish world

(Konai Helu Thaman, “Thinking”)

\section{References}

Beare, Hedley, and Richard Slaughter

I993 Education for the Twenty-first Century. London: Routledge.

Brady, Wendy

I997 Indigenous Australian Education and Globalisation. In Traditions, Modernity and Post-modernity in Comparative Education, edited by V Masemann and A Welch, 4I3-422. Amsterdam: Kluwer.

Fanon, Franz

I967 The Wretched of the Earth. London: Penguin.

I986 Black Skin, White Masks. London: Pluto.

Galtung, Johan

I983 The European Community: A Superpower in the Making. London: George Allen and Unwin.

Hau'ofa, Epeli

I993 Our Sea of Islands. In A New Oceania: Rediscovering Our Sea of Islands, edited by Eric Waddell, Vijay Naidu, and Epeli Hau'ofa, 2-I6. Suva: University of the South Pacific. Reprinted in The Contemporary Pacific 6:I47-I6I (I994).

Hereniko, Vilsoni

2000 Summary of panel discussion on Decolonizing Pacific Studies. $<$ http://www.hawaii.edu/cpis/conference/preconfdisc.html >

Memmi, Albert

I965 The Colonizer and the Colonized. Boston: Beacon.

Rifkin, Jeremy 1992 Biosphere Politics. New York: Harper.

Roberts, Mere

2000 Summary of discussions on Decolonizing Pacific Studies.

Said, Edward $<$ http://www.hawaii.edu/cpis/conference/preconfdisc.html >

I978 Orientalism. New York: Pantheon.

Smith, Linda Tuhiwai

I999 Decolonizing Methodologies: Research and Indigenous Peoples. London: Zed Books. 
Sykes, Roberta B

I989 Black Majority. Melbourne: Hudson.

Teasdale, Bob

I997 Globalisation, Localisation: Impacts and Implications for Teacher Education in the Asia/Pacific Region. Paper presented at 27th Annual Conference of Australian Teacher Education Association, Rockhampton, Queensland.

Teasdale, Bob, and Zane Ma Rhea, editors

2000 Local Knowledge and Wisdom in Higher Education. International Association of Universities Series on Issues in Higher Education. Oxford: Pergamon.

Thaman, Konai Helu

I987 Our Way. In Hingano: Selected Poems, I966-1986, 40. Suva: Mana Publications.

I993 Your Words. In Kakala, 7. Suva: Mana Publications.

I998 Learning to Be: A Perspective from the Pacific Islands. Keynote Address, UNESCO Conference on Education for the 2ist Century in the Asia/ Pacific Region, Melbourne. $30 \mathrm{March}-3$ April.

I999 Thinking. In Songs of Love: New and Selected Poems (1974-I999), I 5. Suva: Mana Publications.

2000 Towards a New Pedagogy: Pacific Cultures in Higher Education. In Local Knowledge and Wisdom in Higher Education, edited by Bob Teasdale and Zane Ma Rhea, 43-45. International Association of Universities Series on Issues in Higher Education. Oxford: Pergamon.

Vine, I

1992 Moral Diversity or Universal Values? In Cultural Diversity and the Schools, edited by James Lynch, Celia Modgil, and Sohan Modgil, Vol I: Education for Cultural Diversity, I69-210. London: Falmer Press. Williams, $\mathrm{R}$

I983 Keywords: A Vocabulary of Culture and Society. Revised edition. London: Fontana.

\section{Abstract}

As part of a larger effort to reflect critically on the nature, scope, and processes of colonialism in Oceania, decolonizing the field of Pacific studies must focus on the impact of colonialism on people's minds-particularly on their ways of knowing, their views of who and what they are, and what they consider worthwhile to teach and to learn. It is essential to challenge the dominance of western philosophy, content, and pedagogy in the lives and the education of Pacific peoples, and to reclaim 
indigenous Oceanic perspectives, knowledge, and wisdom that have been devalued or suppressed. Modern scholars and writers must examine the western disciplinary frameworks within which they have been schooled, as well as the ideas and images of the Pacific they have inherited, in order to move beyond them. The curricula of formal education, particularly higher education, should include indigenous Oceanic knowledge, worldviews, and philosophies of teaching and learning, for several reasons: to contribute to and expand the general knowledge base of higher education; to make university study more meaningful for many students; to validate and legitimize academic work, particularly in the eyes of indigenous peoples; and to enhance collaboration between indigenous and nonindigenous peoples.

KEYWORDS: decolonization, globalization, indigenous worldviews, pedagogy, Pacific education, Pacific Islands studies 